\title{
Lead (II) and zinc (II) ions removal capacity of coarse limestone and rhyolite tuff from aqueous solutions
}

GaBRIELLA NÉMETH - BME, Faculity of Chemical Technology and Biotechnology - gabriella.nemeth1@gmail.com

LILLA MLINÁRIK - BME, Faculty of Civil Engineering, Department of Construction Materials and Engineering Geology • lilla.mlinarik@gmail.com

Ákos TÖRÖK - BME, Faculty of Civil Engineering, Department of Construction Materials and Engineering Geology = torokakos@mail.bme.hu

Érkezett: 2013. 11. 10. - Received: 10. 11. 2013. " http://dx.doi.org/10.14382/epitoanyag-jsbcm.2013.16

\section{Abstract}

The heavy metal adsorption capacity of natural stones is important because it has influence on the dispersion of pollutants. Lead (II) and zinc (II) ions removal capacity of two Hungarian stones (coarse limestone and rhyolite tuff) were analysed under laboratory conditions. Petrophysical parameters of rock samples were determined at air-dried and in water saturated conditions: apparent density, capillary water absorption, ultrasound pulse velocity, open and full porosity. The powdered rock samples and specimens were put into lead-nitrate and zinc-sulphate solutions and the amounts of adsorbed lead (II) and zinc (II) ions were identified by titration of the residual solution. According to the tests, the powdered and cylindrical rock specimens could reduce the concentration of lead (II) and zinc (II) ions in the heavy metal solutions. The results suggest that these two types of rocks could be used in environmental protection technologies such as material of permeable reactive barrier.

Keywords: lead (II), zinc (II), coarse limestone, rhyolite tuff, environmental protection

\section{Introduction}

Waste water with heavy metal content is considered to be hazardous both for human life and for the environment due to their acute toxicity and non-biodegradability. In the last few decades several technologies have been developed to remove heavy metal ions from industrial waste water and prevent the environment from heavy metal pollution. Despite of the high efficiency of the applied technologies (like using activated carbon), these are very expensive and in some cases continuously chemical input and/or pre-treatment is needed. The removals of metals are not always incomplete and the follow-up treatment of the used adsorber materials is not highly elaborated [1]. Therefore, the search of low-cost alternative adsorbents is essential.

Some materials, like porous natural stones, could immobilize heavy metals from industrial waste water and from polluted groundwater according to their chemical and physical properties. Chemical features (especially mineralogical composition) of limestone and rhyolite tuff could bind certain contaminants (with adsorption or chemical precipitation on the mineral surface), and subtract them from the natural geochemical cycle. Physical characteristics (porosity, permeability, and $\mathrm{pH}$ ) of these two stones could influence the accessibility of the solutions which contain heavy metals [2-5]. These properties of natural porous rocks may prefer to use in many industrial areas, such as waste water and flue gas cleaning processes, as well as agricultural practices of soil improvement. Recently, natural stones are used as an adsorbents in permeable reactive barriers in polluted groundwater cleaning processes [6-9] and also as host rocks of hazardous waste deposits $[10,11]$.
Lilla MLINÁRIK

(1986) chemical engineer (MSc, 2012). Graduated in 2012, at the Department of

Physical Chemistry and Materials Science, of

the Budapest University of Technology and Economics. Started her research work in 2009 in the field of concrete additives (superplasticizers). Since 2012, she has been PhD student at the Budapest University of Technology and

Economics, Department of Construction

Materials and Engineering Geology. Her field of research is the influence of supplementary cementing materials on the chemical resistance of cements.

Ákos TöRöK (1963) geologist (MSc, 1986), MSc in Environmental Engineering and Science (1993), PhD (1995), full professor at the Budapest University of Technology, Faculty of

Civil Engineering. Member of the International Association of Engineering Geologists IAEG (President of Hungarian National Group), International Society of Rock Mechanics ISRM (President of Hungarian National Group), Hungarian Geological Society (President of the Engineering Geology and Environmental Geology Division). Main field of interest: engineering geology, applied geology, sediment geology, carbonate sedimentology, material testing and protection of heritage buildings.

Lead and zinc are one of the most common contaminants of industrial waste waters. Storage batteries, printing, painting dying, mining, metallurgy and fuel combustion are the source of these heavy metals [12].

Lead and zinc poisoning could cause health problem, such as the damage of liver and kidney, mental retardation, neurological problems. Therefore the reduction of the concentration of lead, zinc and other heavy metal ions in waste water is very indispensable.

The aims of this paper were to observe the spread of heavy metal solution in Hungarian porous coarse limestone and rhyolite tuff, determine the effect of these two rocks on solutions with lead and zinc content, and recommend environmental protecting applications of the examined porous rocks.

\section{Materials and methods}

\subsection{Materials}

In this study natural rhyolite tuff and coarse limestone were used as adsorbent materials (Fig. 1).

The rhyolite tuff of Demjén, from Bükkalja (southwest of Eger), is a grey, pumice (centimeter-sized) rich and Miocene pyroclastic rock. In matrix biotite and quartz could be recognized. Three typical tuff scattering levels (lower, middle and upper) could be found at Bükkalja. The examined rhyolite tuff was from the middle tuff level. The thickness range of this tuff level is between 2-20 $\mathrm{m}$ [13]. 


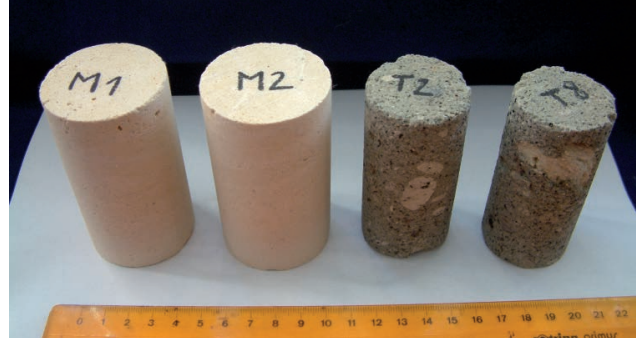

Fig. 1. Cylindrical coarse limestone and rhyolite tuff specimens

1. ábra Hengeres durva mészkö és riolittufa próbatestek

The coarse limestone of Sóskút is a Miocene sedimentary rock. According to its mineralogy and texture, several variations could be identified. During our examination we used the yellowishwhite, fine grained ooid rich version. The typical texture of Sóskút coarse limestone is ooid grainstone/packstone [14] by microscopic studies. This limestone could be found in two formations: the most common Tinnyei Limestone Formation (Sarmation) and Rákosi Limestone Formation (Baden). The largest volume of this limestone was mined at Sóskút, Biatorbágy and nearby the capital city of Hungary. It used like building materials of historical monuments in Budapest [15].

\subsection{Petrophysical examination of rock samples}

We determined basic petrophysical parameters of rock samples in water saturated and air-dried condition: apparent density, capillary water absorption, ultrasound pulse velocity, open and full porosity.

\subsection{Preparation of rock samples}

The preparation of rock samples was made in two steps. First of all, the coarse limestone and rhyolite tuff were grounded in an agate mortal. The grain size was less than $100 \mu \mathrm{m}$.

The examinations were carried out by $5 \mathrm{~g}$ powdered rock samples (coarse limestone, rhyolite tuff) in contact with 25 $\mathrm{ml}$ of $\mathrm{pH}$ neutral heavy metal solutions. The solutions were prepared from basic salts: lead-nitrate $\mathrm{Pb}\left(\mathrm{NO}_{3}\right)_{2}$ and zincsulphate $\mathrm{ZnSO}_{4}$. The concentrations of each solution were 1000 ppm and the temperature was $22^{\circ} \mathrm{C}$. After 24 hours, powdered samples were filtered through semi-coarse filter paper and dried at $50{ }^{\circ} \mathrm{C}$. The residual heavy metal solutions were collected in plastic bottles until analytical examinations.

In the next step the cylindrical rock specimens (height: $8 \mathrm{~cm}$, diameter: $4 \mathrm{~cm}$ ) were drilled by diamond drill-bit from coarse limestone and rhyolite tuff. Dried rock specimens were soaked into lead-nitrate or zinc-sulphate heavy metal solutions. The concentrations of the solutions were $1000 \mathrm{ppm}$, and the temperature was $22^{\circ} \mathrm{C}$. After the 24 hours retention time, the rock specimens were dried at $50{ }^{\circ} \mathrm{C}$ and the residual heavy metal solutions were stored also in plastic bottles.

\subsection{Wet chemical analysis}

After the preparation of the rock samples we determined the concentration of the solutions with heavy metal content by titrimetric (chelatometry) analytical method. During the examination the concentrations of the Complexon solutions were 0.005 and $0.01 \mathrm{M}$.

\subsection{Characterization of raw and treated materials}

Characterization of untreated and treated coarse limestone and rhyolite tuff was carried out by X-ray diffraction (XRD). We used Philips diffractometer (generator: PW 1130; goniometer: PW1050; npd Control counter: PW3710, copper anode and monochromator). Accelerating voltage: $40 \mathrm{kV}$, amperage: 30 $\mathrm{mA}$, measuring angle: $3-70^{\circ}$. The evaluation was made by Philips PW 1877 Automated Powder Diffraction (Version 3.5B) software.

\section{Results}

\subsection{Petrophysical properties of examined porous rocks}

According to the petrophysical studies the coarse limestone's apparent density, ultrasound pulse velocity and capillary water absorption were larger than the rhyolite tuff's, but the full porosity was less. According to the results, the cause of the difference is the larger amount of pumice in rhyolite tuff. The pore system of pumice is closed, so the water could not migrate so deeply in the stone. This is the reason, why the capillary water absorption and the full porosity values are lower in rhyolite tuff than in coarse limestone. Pores of pumice are mainly filled by air and have bigger pore diameter, so the ultrasound pulse velocity of rhyolite tuff is reduced. Because of the low density of pumice $\left(<1 \mathrm{~g} / \mathrm{cm}^{3}\right)$ the high amounts of it, could decrease the apparent density of rhyolite tuff. Nevertheless, the two rock open porosity values were high (>30\%) and approximately the same. This result suggests, that both types of rock are sufficiently porous to use as migration passage of the experiment solutions (Table 1).

\begin{tabular}{lcc}
\multicolumn{1}{c}{ Tests } & $\begin{array}{c}\text { Coarse } \\
\text { limestone }\end{array}$ & $\begin{array}{c}\text { Rhyolite } \\
\text { tuff }\end{array}$ \\
\hline Apparent density $\left(\mathbf{g} / \mathbf{c m}^{\mathbf{3}}\right)$ & 2.70 & 2.45 \\
\hline Ultrasound pulse velocity $(\mathbf{m} / \mathbf{s})$ & $2580-3165$ & $1921-2255$ \\
\hline Capillary water absorption $\mathbf{( k g / \mathbf { m } ^ { 2 } )}$ & $27-26.9$ & $21.1-21.4$ \\
\hline Open porosity (\%) & 30.1 & 30.2 \\
\hline Total porosity (\%) & 30.2 & 39.4 \\
\hline
\end{tabular}

Table 1. Results of petrophysical analysis

1. táblázat Közetfizikai vizsgálatok eredményei

\subsection{Wet chemical analysis}

In accordance with wet chemicals analysis 1 kilogram of powdered rock samples could immobilize 5-10 times more lead (II) and zinc (II) ions from heavy metal solutions than 1 kilogram of cylindrical rock specimens (Fig. 2 to 3 ). These phenomena could be explained by the greater specific surface area of powdered rock samples than cylindrical rock specimens.

It was also found, that powdered rock samples could bind the same quantity of heavy metals (lead (II) and zinc (II)) against to rock specimens. The cause is the mineralogical content of the examined rocks. Rhyolite tuff contains a lot of glass beside other minerals, like biotite, quartz, feldspars. Glass has several reactive ligands, which can bind heavy metals, like lead and zinc also. This is the same situation with pumice. Demjén rhyolite 
tuff includes many pumice fragments, which are built up mostly from glass. This kind of clasts could increase the binding features of rhyolite tuff. In contrast, coarse limestone is built up only from calcite minerals. This rock is quite homogeneous. Calcite has less reactive functional groups, which could bind heavy metals, but it does not mean that this mineral is not able to do it.

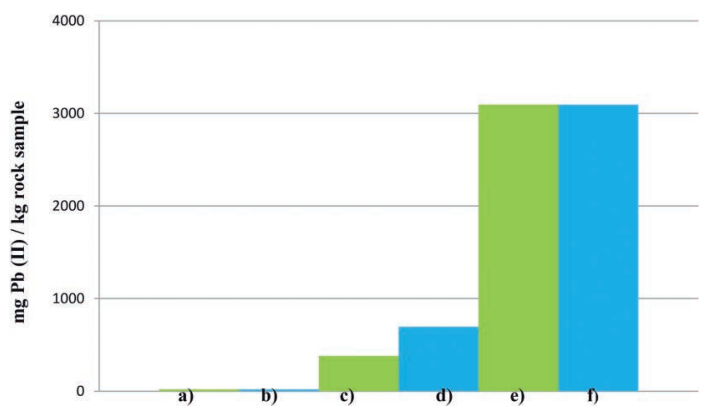

Fig. 2. Lead (II) immobilization from lead-nitrate aqueous solution (1000 ppm) by rock samples in various physical conditions: a) untreated coarse limestone, b) untreated rhyolite tuff, c) soaked coarse limestone specimens, d) soaked rhyolite tuff specimens, e) powdered and soaked coarse limestone, f) powdered and soaked rhyolite tuff

2. ábra Különböző fizikai állapotú kőzetminták ólom (II) megkötő képessége ólomnitrát oldatból (1000 ppm): a) oldattal nem kezelt durva mészkő; b) oldattal nem kezelt riolittufa, c) oldatba áztatott durva mészkö próbatestek, d) oldatba áztatott riolittufa próbatestek, e) poritott és oldatba áztatott durva mészkö, f) poritott és oldatba áztatott riolittufa

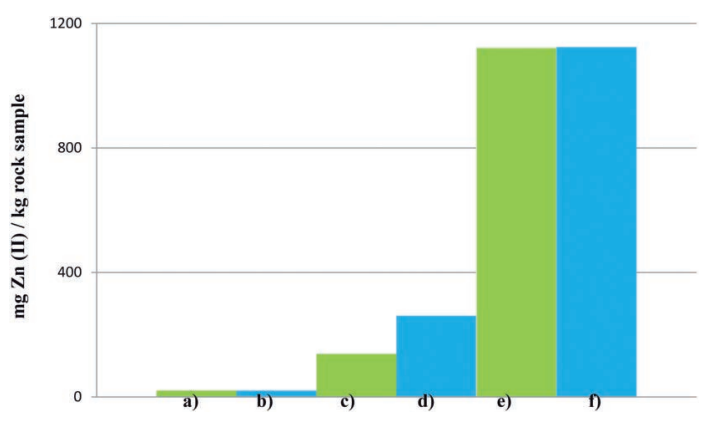

Fig. 3. Zinc (II) immobilization from zinc-sulphate aqueous solution (1000 ppm) by rock samples in various physical conditions: a) untreated coarse limestone, b) untreated rhyolite tuff, c) soaked coarse limestone specimens, d) soaked rhyolite tuff specimens, e) powdered and soaked coarse limestone, f) powdered and soaked rhyolite tuff

3. ábra Különböző fizikai állapotú közetminták cink (II) megkötő képessége cinkszulfát oldatból (1000 ppm): a) oldattal nem kezelt durva mészkő; b) oldattal nem kezelt riolittufa, c) oldatba áztatott durva mészkö próbatestek, d) oldatba áztatott riolittufa próbatestek, e) poritott és oldatba áztatott durva mészkö, f) poritott és oldatba áztatott riolittufa

According to wet chemical analysis, rhyolite tuff specimens could bind much bigger quantity of heavy metals (lead (II) and zinc (II)), than coarse limestone specimens (Fig. 2 to 3). It has a physical explanation. Coarse limestone has much smaller pore diameter, than rhyolite tuff. That's why pores in coarse limestone could be clogged by precipitated minerals (nitrate and sulphate salts) and the migration of heavy metal solution could stop. In this case high amount of the minerals in coarse limestone do not have a chance to contact with heavy metals, and the immobilization will not happen.

It is also important, that both of the examined rocks (in powdered or in specimens form) could bind more lead (II) than zinc (II) ions (Fig. 2 to 3). It could be explained by the difference of mobility between zinc (II) and lead (II) ions. In aqueous solution zinc (II) ions are more mobile than lead (II) ions. The rate of immobilisation on the solid phase (minerals), in the case of lead (II) ions, is higher than zinc (II) ions.

\subsection{Characterization of raw and treated materials}

The X-ray diffraction examinations suggest that untreated rock samples did not contains any lead or zinc mineral phases (Fig. 4 to 5). After wet chemical preparation it was found that coarse limestone did not contain heavy metal ions (Fig. 5), but rhyolite tuff contained lead and zinc mineral phases (Fig. 4). It suggests, that heavy metal removal was taken place by chemical precipitation (lead or zinc mineral phases) in rhyolite tuff. Despite the facts, that lead and zinc mineral phases were not determined by X-ray diffraction in coarse limestone, it does not mean that coarse limestone was not able to immobilize heavy metals from their solution. Wet analysis proved that coarse limestone could bind heavy metals from their aqueous solutions, but probably the process did not take place by chemical precipitation, but adsorption. This type of physical adsorption could not demonstrated by X-ray diffraction. This method is usable for phase analysis. This theory needs to be proved by scanning electron microscope (SEM) observations in the future.

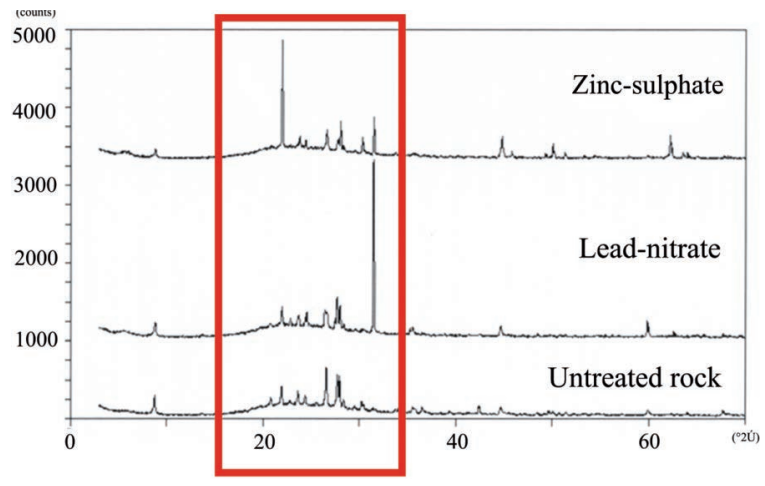

Fig. 4. X-ray diffractogram of rhyolite tuff 4. ábra Riolittufa röntgen diffraktogramja

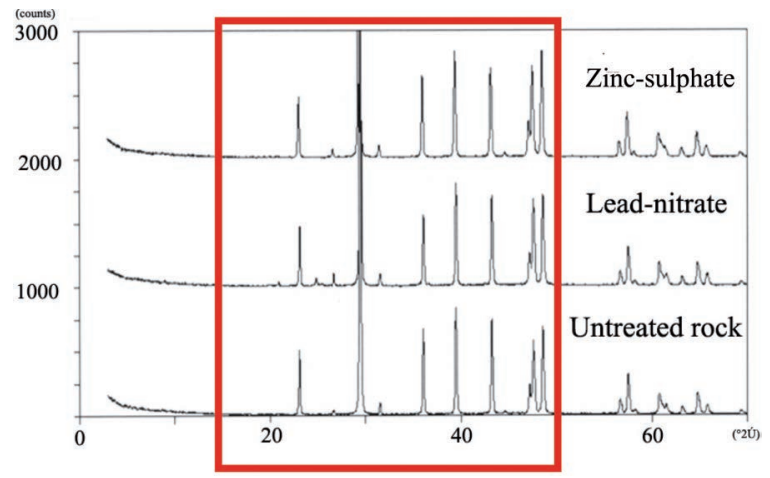

Fig. 5. X-ray diffractogram of coarse limestone 5. ábra Durva mészkö röntgen diffraktogramja

\section{Conclusions}

Lead (II) and zinc (II) ions could be very successfully removed from aqueous solutions by chemical precipitation and adsorption process on Demjén rhyolite tuff and Sóskút coarse limestone. Lead (II) and zinc (II) ions were bound from aqueous solution by both examined rocks, but heavy metal removal capacity of rhyolite tuff specimens was greater. 
Lead (II) ion removal efficiency was higher than zinc (II) ion immobilization in both types of rocks. The binding capacity of powdered rock sample was greater than rock specimens. According to X-ray diffraction analysis, heavy metals were mainly immobilized by chemical precipitation (in crystal form), but physical adsorption processes are not excluded.

Rhyolite tuff from Demjén and coarse limestone from Sóskút are widespread in Hungary. They are readily available, relatively affordablerawmaterialsandaccordingtoourinvestigationsthese natural stones have quite high heavy metal removal efficiency from aqueous solution, with high concentration. Depending on the desired reduction of heavy metal concentration in aqueous systems, we recommended these two rocks as adsorbent materials in applied environmental processes, such as treating of polluted ground water by permeable reactive barrier. Instead of the raw coarse limestone and rhyolite tuff, we also suggest the application of used building stones and materials too.

\section{References}

[1] Brown, P. A. - Gill, S. A. - Allen, S. J.: Metal removal from wastewater using peat. Water Research. 34(16), 2000, pp. 3907-3916, http://dx.doi. org/10.1016/S0043-1354(00)00152-4

[2] Aziz, H. A. - Adlan, M. N. - Ariffin, K. S.: Heavy metals (Cd, Pb, Zn, $\mathrm{Ni}, \mathrm{Cu}$ and $\mathrm{Cr}(\mathrm{III}))$ removal from water in Malaysia: Post treated by high quality limestone. Bioresource Technology. 99(6), 2008, pp. 1578-1583, http://dx.doi.org/10.1016/j.biortech.2007.04.007

[3] Yao, Z. - Zhou, L. - Bao, Z. - Gao, P. - Sun, X.: High efficiency of heavy metal removal in mine water by limestone. Chinese Journal of Geochemistry. 28(3), 2009, pp. 293-298, http://dx.doi.org/10.1007/s11631-010-0120-z

[4] Ismael, I. S. - Melegy, A. - Kratochvil, T.: Lead removal from aqueous solution by natural and pretreated zeolites. Geotechnical and Geological Engineering. Vol. 30, 2012, pp. 253-262, http://dx.doi.org/10.1007/s10706011-9466-1

[5] Sdiri, A. - Higashi, T. - Jamoussi, F. - Bouaziz, S.: Effect of impurities on the removal of heavy metals by natural limestones in aqueous system. Journal of Environmental Management. 93(1), 2012, pp. 245-253, http:// dx.doi.org/10.1016/j.jenvman.2011.08.002

[6] Roehl, K. E. - Meggyes, T. - Simon, F. G. - Stewart, D. I.: Long-term performance of permeable reactive barriers. Elsevier Science. 2005, pp. $1-25$.

[7] Thiruvenkatachari, R. - Vigneswaran, S. - Naidu, R.: Permeable reactive barrier for ground water remediation. Journal of Industrial and Engineering Chemistry. Vol. 14, 2008, pp. 145-156, http://dx.doi.org/10.1016/j.jiec.2007.10.001

[8] Moraci, N. - Calabró, P. S.: Heavy metals removal and hydraulic performance in zero-valent iron/pumice permeable reactive barriers. Journal of Environmental Management. Vol. 91, 2010, pp. 2336-2341, http://dx.doi.org/10.1016/j.jenvman.2010.06.019

[9] Wang, Y. - Sikora, S. - Townsend, T. G.: Ferrous iron removal by limestone and cruched concrete in dynamic flow columns. Journal of Environmental Management. Vol. 124, 2013, pp. 165-171, http://dx.doi.org/10.1016/j. jenvman.2013.02.018

[10] Spycher, N. F. - Sonnenthal, E. L. - Apps, J. A.: Fluid flow and reactive transport around potential nuclear waste emplacement tunnels at Yucca Mountain. Nevada Journal of Contaminant Hydrology. Vol. 62-63, 2003, pp. 653-673, http://dx.doi.org/10.1016/S0169-7722(02)00183-3

[11] U.S. Department of Energy-Office of Civilian Radioactive Waste Management: Yucca Mountain Science and Engineering Report-Revision 1., DOE, 2002.

[12] Ramos, R. L. - Jacome, L. A. B. - Barron, J. M. - Rubio, L. F. - Coronado, R. M. G.: Adsorption of zinc (II) from an aqueous solution onto activated carbon. Journal of Hazardous Materials. Vol. 90, 2002, pp. 27-38, http:// dx.doi.org/10.1016/S0304-3894(01)00333-8

[13] Hámor, G.: Genesis and evolution of the Pannonian Basin. In: Haas, J. (Ed.): Geology of Hungary. Eötvös Kiadó. Budapest, 2001, pp. 193-242.

[14] Török, Á.: Oolitic limestone in polluted atmospheric environment in Budapest: weathering phenomena and alterations in physical properties. In: Siegesmund, S., Weiss, T. S., Vollbrecht, A. (Eds.): Natural Stones, Weathering Phenomena, Conservation Strategies and Case Studies. Geological Society. Special publication. London, 205, 2002, pp. 363-379.

[15] Török, Á.: Durva mészkőből épült műemlékek károsodása légszennyezés hatására. In: Török, Á. (Ed.):Mérnökgeológiai Jubileumi Konferencia. Müegyetemi Kiadó. Budapest, 2003, pp. 287-301.

Ref.:

Gabriella Németh - Lilla Mlinárik - Ákos Török: Lead (II) and zinc (II) ions removal capacity of coarse limestone and rhyolite tuff from aqueous solutions Építőanyag, 65. évf. 3. szám (2013), 86-89. p. http://dx.doi.org/10.14382/epitoanyag-jsbcm.2013.16

Riolittufa és durva mészkő oldott állapotú ólom (II) és cink (II) ion megkötő képességének vizsgálata

A kôzetek nehézfém megkötố képessége igen fontos az elôforduló környezeti szennyezôdések terjedésének befolyásolásában. Vizsgálataink során két hazai kôzettípus (durva mészkô és riolittufa) ólom (II) és cink (II) megkötố képességét vizsgáltuk laboratóriumi körülmények között. A vizsgálatok során meghatároztuk a kôzetek kôzetfizikai paramétereit víztelített és légszáraz állapotban: anyagsűrūség, kapilláris vízfelvétel, ultrahang terjedési sebesség, nyílt és összporozitás. A porított, valamint a kôzetekbôl fúrt próbatesteket ólom-nitrát, illetve cink-szulfát oldatba áztattunk, majd nedves analitikai (kelatometriás) módszerrel meghatároztuk a visszamaradt oldat ólom (II) és cink (II) ion koncentrációját. A vizsgálatok szerint a porított kôzzetminták, és a kôzetekbốl fúrt hengeres próbatestek is képesek voltak az ólom (II) és cink (II) ionok koncentrációját csökkenteni a nehézfém tartalmú oldatokban. Az eredmények alapján megállapítható, hogy a vizsgált két kôzet alkalmas lehet késốbbi környezetvédelmi eljárásokban való alkalmazásra, többek között, mint reaktiv gátanyag.

Kulcsszavak: ólom (II), cink (II), durva mészkô, riolittufa, környezetvédelem

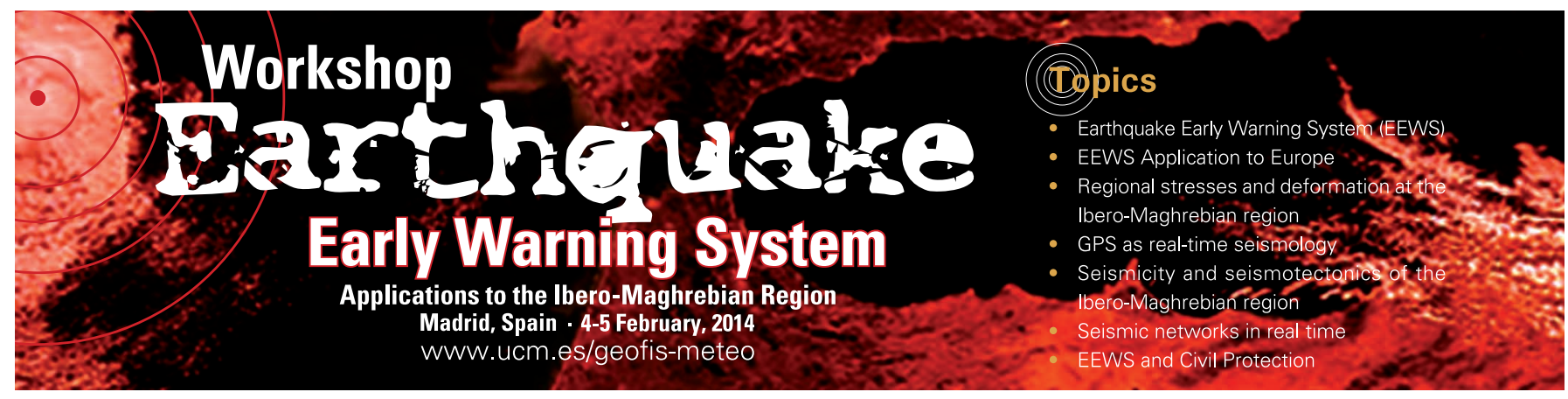

